\title{
Effect of processed maize stover as an alternative energy source in swine production
}

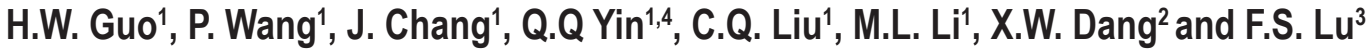 \\ ${ }^{1}$ Henan Agricultural University, College of Animal Science and Veterinary Medicine \\ 218 Pingan Avenue, Zhengzhou 450046, China \\ ${ }^{2}$ Henan Delin Biological Product Co., Ltd., 1 Taihong Avenue, Xinxiang 453000, China \\ ${ }^{3}$ Henan Puai Feed Co., Ltd., 123 Zhanghuatai Road, Shangshui 466000, China
}

KEY WORD: pigs, processed maize stover, feed intake, daily gain, nutrient digestibility

Received: 5 April 2020

Revised: 19 April 2020

Accepted: 21 May 2020

${ }^{4}$ Corresponding author:

e-mail: qqy1964@126.com
ABSTRACT. In order to increase the nutritive values of maize stover, the processes of steam explosion and microbial fermentation with Aspergillus oryzae were used to produce processed maize stover (PMS). In the digestive experiment on swine it was shown that dietary digestible energy (DE) was decreased when PMS substitute rates for maize meal were increased from 5 to $15 \%(P<0.05)$. In each of two-stage swine feeding experiment were 5 groups with 3 replications in each: group 1 - control, groups 2-4 - diets supplemented with 5,10 or $15 \%$ PMS, respectively (as a replacement of the same amount of maize meal), group 5 - diet supplemented with $10 \%$ PMS with DE level the same as in the control group. It was indicated that average daily gain and nutrient digestibility were similar in groups with 0 and $5 \%$ PMS addition but were decreased when PMS addition increased from 5 to $15 \%$. It can be concluded that the optimal levels of PMS in diets were below $10 \%$ for younger pigs and $15 \%$ for older ones. PMS addition could help to increase faecal enzyme activity and decrease swine diarrhoea rates. So, the insights that optimal PMS levels could relieve shortage of energy feedstuffs were provided in this study.

\section{Introduction}

Energy sources and edible carbohydrate shortages are the world-wide problems. Lignocellulose, which yearly production is about 7 billion tons with $70 \%$ belonging to crop stalks, is the largest renewable energy source (Kaur and Kuhad, 2019). Unfortunately, most of it is discarded, buried or burned in the field because lignin can maintain the cell wall permeability and support the plant cell wall, which is combined with cellulose and hemicelluloses to form crystal structure to resist enzymatic hydrolysis and microbial attack for the further application (Saha et al., 2005). If lignocellulose is transferred to low-molecular carbohydrate, it will help to solve energy crisis.
In numerous studies it was shown that physical, chemical and biological treatments are the effective methods improving the potential value of crop straw to be used as feedstuff for monogastric animals, at the same time replacing the conventional grains such as maize, wheat, rice and others (Chang et al., 2015; Aguilar et al., 2018; Kaur and Kuhad, 2019; Siddhu et al., 2019; Wang et al., 2019). In our previous research we have shown that Aspergillus oryzae can produce numerous kinds of enzymes such as protease, amylase, cellulase to help degrade maize stover (Chang et al., 2015); therefore, it is appropriate for feed fermentation.

The optimal dietary fibre content is beneficial for the development of pig intestine and the reduction 
of diarrhoea rate, however high dietary fibre level can reduce the nutrient digestibility (Chen et al., 2015). It was reported that the optimal dietary crude fibre level for pig growth is about $6 \%$ (Le Gall et al., 2009; Molist et al., 2014). The increased abundance of cellulose-degrading bacteria in the colon after addition of $10 \%$ oat bran to the diet of weaned piglets was observed by $\mathrm{He}$ et al. (2018). Luo et al. (2018) reported that the addition of pea fibre to pig diet promoted productions of butyrate and volatile fatty acids in the intestinal tract. So, different fibre sources and levels may have the different effects on pig responses (Slavin et al., 2009).

Maize stover includes $70-85 \%$ lignocellulose and some protein, fat, calcium, phosphorus and minerals, which have a potential value in animal production (Graminha et al., 2008; Mourtzinis et al., 2016). The physical, chemical and biological treatments will help to destroy maize straw structure for further lignocellulose degradation and as a result to make processed maize stover (PMS) for broiler growth (Chang et al., 2015; Wang et al., 2019).

In order to solve the problems of energy sources and edible carbohydrate shortages in pig production, this study was focused on improving by the physical and biological methods the nutritional value of maize stover as a possible substitute of maize meal.

\section{Material and methods}

\section{The preparation of the maize stover}

The maize stover was obtained from the experimental farm in Henan Agricultural University, Zhengzhou (China). The air-dried maize stover was hammer-milled and screened to obtain pieces of 210 $\mathrm{mm}$ in size. The steam explosion of maize stover was carried out by a steam explosion equipment (QBS-200, Zhengdao Machine Factory, Hebi, China). About $50 \mathrm{~kg}$ mashed maize stover was put into a steam chamber. The steam was adjusted to $2.5 \mathrm{MPa}$ pressure and kept for $200 \mathrm{~s}$, and then suddenly released at the end of treatment to give explosion effect. The exploded samples were collected and dried naturally to $90.1 \%$ dry matter content before microbial fermentation.

\section{Solid-state fermentation of maize stover}

The fermented materials were composed of $90 \%$ exploded maize stover, $4 \%$ maize meal, $3 \%$ wheat bran, $3 \%$ soybean meal, in which $60 \%$ of minerals was added and mixed (v/w). The $\mathrm{pH}$ value of the fermented materials was adjusted to 7.0 by $\mathrm{Ca}(\mathrm{OH})_{2}$.
The mineral mixture contained $(\mathrm{g} / \mathrm{l}):\left(\mathrm{NH}_{4}\right)_{2} \mathrm{SO}_{4}$ 1.4, $\mathrm{KH}_{2} \mathrm{PO}_{4} 2.0, \mathrm{MgSO}_{4} 0.3, \mathrm{CaCl}_{2} 0.3, \mathrm{NaCl} 0.5$, $\mathrm{FeSO}_{4} 0.0050, \mathrm{MnSO}_{4} 0.0016, \mathrm{ZnCl}_{2} 0.0017, \mathrm{CoCl}_{2}$ 0.0020 . All the above materials were autoclaved at $121{ }^{\circ} \mathrm{C}$ for $15 \mathrm{~min}$, and then $4 \%(\mathrm{v} / \mathrm{w})$ Aspergillus oryzae suspension $\left(1 \times 10^{6} \mathrm{spores} / \mathrm{ml}\right)$ was added and mixed. Aspergillus oryzae suspension was prepared as the following: Aspergillus oryzae was incubated in the flasks containing the above fermented materials in which the exploded maize stover was replaced by the wheat bran, the suspension was obtained by adding normal saline at 10:1 (v/w) after 6 days of incubation at $30{ }^{\circ} \mathrm{C}$. The microbial fermentation of maize stover was carried out at $30{ }^{\circ} \mathrm{C}$ for 6 days. The fermented sample was dried at $65{ }^{\circ} \mathrm{C}$ up to about $90 \%$ dry matter, and then ground to the size of $420 \mu \mathrm{m}$.

\section{Nutrient determinations}

Cellulose and hemicelluloses contents in the samples were determined in line with the previous protocol (Van Soest et al., 1991). The process was as following: $0.5 \mathrm{~g}$ sample was added into a nylon bag and sealed. Neutral detergent fibre (NDF) and acid detergent fibre (ADF) measurements were conducted by boiling in neutral detergent solution and acid detergent solution for $60 \mathrm{~min}$, respectively. Both of them were washed with boiling water until no detergent was detected, and then dried at $105^{\circ} \mathrm{C}$. After acid detergent extraction, the nylon bag was dipped in $72 \%(\mathrm{v} / \mathrm{v})$ sulphuric acid for $3 \mathrm{~h}$, washed until no sulphuric acid was detected, and dried at $105{ }^{\circ} \mathrm{C}$. The residues in nylon bag were ashed at $600{ }^{\circ} \mathrm{C}$ to obtain the residual ash. The hemicelluloses and cellulose contents were calculated as the following:

hemicellulose $(\%)=\mathrm{NDF}(\%)-\mathrm{ADF}(\%)$, cellulose $(\%)=\mathrm{ADF}(\%)$ - residues with

$72 \%$ sulphuric acid treatment (\%).

About $5.0 \mathrm{~g}$ native and differently treated maize straw were soaked in $50 \mathrm{ml}$ distilled water for $24 \mathrm{~h}$ at $40{ }^{\circ} \mathrm{C}$ and then filtered. The filtrate was used to measure total reducing sugar content with dinitrosalicylic acid (DNS) method (Miller, 1959). Dry matter and crude protein contents in PMS, diets and faeces were determined according to international procedures of AOAC (1990). Calcium (Ca) and phosphorus $(\mathrm{P})$ contents were determined with potassium permanganate $\left(\mathrm{KMnO}_{4}\right)$ and ammonium molybdate $\left(\left(\mathrm{NH}_{4}\right)_{6} \mathrm{Mo}_{7} \mathrm{O}_{24}\right)$ protocols (Jurgens, 1997). The gross energy in the diets and faeces was determined with an oxygen bomb calorimeter (IKA-C2000, IKA Instrument Company, Staufen, Germany). 


\section{Experimental design and animal feeding management}

Prior to the two-stage feeding experiment, 7-days adaptive phase was conducted. In the earlier feeding stage, 120 ninety-day-old barrows (Landrace $\times$ Yorkshire) were assigned to 5 groups with 3 replications in each group, and 8 barrows for each replication in one pen. The experimental period was 30 days. In the later feeding stage, 105 barrows at the age of 120 days were assigned to 5 groups with 3 replications in each group, and 7 barrows for each replication in one pen. The experimental period lasted also 30 days. The feeding experiment design is presented in Table 1.

Table 1. Experimental design

\begin{tabular}{ll}
\hline Group & Processed maize stover (PMS) contents in the basal diets \\
\hline 1 & The basal diet (control group) \\
2 & Maize meal in basal diet replaced by $5 \%$ PMS \\
3 & Maize meal in basal diet replaced by $10 \%$ PMS \\
4 & Maize meal in basal diet replaced by $15 \%$ PMS \\
5 & $\begin{array}{l}\text { Maize meal in basal diet replaced by } 10 \% \text { PMS (dietary } \\
\text { digestible energy content was adjusted to the same levels as } \\
\text { control group with soybean oil) }\end{array}$ \\
\hline
\end{tabular}

The dry mash diets and water were given ad libitum. The compositions and nutrient levels of the experimental diets are shown in Table 2.

All animals were managed according to the guidelines for care and use of experimental animals approved by The Ethics Committee of Henan Agricultural University (SKLAB-B-2010-003-01).

\section{Productive performance}

During both feeding experiments, the initial and final body weights of pigs in each replication were measured, and then average daily gain (ADG) was calculated. Feed intake in each replication was measured daily, and average daily feed intake (ADFI) was calculated. Feed conversion rate (FCR) was calculated based on the ratio of ADFI/ADG. The pigs with watery faeces around anus were considered as having diarrhoea, the diarrhoea rate was calculated as following: number of pigs with diarrhoea / total pigs.

\section{Nutrient digestibility determination}

There were two digestion trials. The first one was to measure digestible energy (DE) contents in diets containing different levels of PMS for preparing the diet in group 5. In the first digestion trial for DE determination, twenty castrated fattening

Table 2. Feed compositions and nutrient levels of the diets, $\%$

\begin{tabular}{|c|c|c|c|c|c|c|c|c|c|c|}
\hline \multirow{3}{*}{ Indices } & \multicolumn{5}{|c|}{$90-120$ days } & \multicolumn{5}{|c|}{ 120-150 days } \\
\hline & \multicolumn{5}{|c|}{ Groups $^{1}$} & \multicolumn{5}{|c|}{ Groups $^{1}$} \\
\hline & 1 & 2 & 3 & 4 & 5 & 1 & 2 & 3 & 4 & 5 \\
\hline \multicolumn{11}{|l|}{ Feed composition } \\
\hline maize meal & 66.00 & 61.47 & 57.02 & 52.60 & 54.00 & 72.35 & 67.81 & 63.47 & 58.80 & 60.17 \\
\hline soybean meal & 24.50 & 24.29 & 24.00 & 23.65 & 24.39 & 20.70 & 20.50 & 20.10 & 20.00 & 20.70 \\
\hline processed maize stover & 0.00 & 5.00 & 10.00 & 15.00 & 10.00 & 0.00 & 5.00 & 10.00 & 15.00 & 10.00 \\
\hline wheat bran & 5.00 & 5.00 & 5.00 & 5.00 & 5.00 & 5.00 & 5.00 & 5.00 & 5.00 & 5.00 \\
\hline calcium carbonate & 0.83 & 0.57 & 0.30 & 0.05 & 0.30 & 0.83 & 0.57 & 0.30 & 0.05 & 0.30 \\
\hline calcium phosphate & 0.94 & 0.94 & 0.94 & 0.94 & 0.94 & 0.94 & 0.94 & 0.94 & 0.94 & 0.94 \\
\hline lysine & 0.10 & 0.10 & 0.11 & 0.13 & 0.11 & 0.10 & 0.10 & 0.11 & 0.13 & 0.11 \\
\hline calcium salt & 0.58 & 0.58 & 0.58 & 0.58 & 0.58 & 0.58 & 0.58 & 0.58 & 0.58 & 0.58 \\
\hline soybean oil & 1.05 & 1.05 & 1.05 & 1.05 & 3.68 & 0.50 & 0.50 & 0.50 & 0.50 & 3.20 \\
\hline premix $^{2}$ & 1.00 & 1.00 & 1.00 & 1.00 & 1.00 & 1.00 & 1.00 & 1.00 & 1.00 & 1.00 \\
\hline \multicolumn{11}{|l|}{ Nutrient levels } \\
\hline $\mathrm{DE}, \mathrm{MJ} / \mathrm{kg}$ & 13.60 & 13.26 & 13.02 & 12.72 & 13.61 & 13.60 & 13.31 & 13.01 & 12.72 & 13.60 \\
\hline crude protein & 17.51 & 17.49 & 17.48 & 17.47 & 17.50 & 16.01 & 15.99 & 15.98 & 15.99 & 16.02 \\
\hline NDF & 16.23 & 18.05 & 20.13 & 21.98 & 20.07 & 17.88 & 19.81 & 21.72 & 23.64 & 21.73 \\
\hline ADF & 5.71 & 7.53 & 9.56 & 11.32 & 9.61 & 6.67 & 8.57 & 10.51 & 12.43 & 10.49 \\
\hline calcium & 0.66 & 0.67 & 0.68 & 0.66 & 0.67 & 0.59 & 0.61 & 0.59 & 0.58 & 0.60 \\
\hline phosphorus & 0.53 & 0.54 & 0.54 & 0.55 & 0.54 & 0.49 & 0.51 & 0.49 & 0.51 & 0.51 \\
\hline lysine & 0.95 & 0.95 & 0.95 & 0.95 & 0.95 & 0.85 & 0.85 & 0.85 & 0.85 & 0.85 \\
\hline
\end{tabular}

${ }^{1}$ groups according to Table $1 ;{ }^{2}$ premix composition (per kg of diet), mg: Cu (copper sulphate) 2597, Fe (ferrous sulphate) 2945, Zn (zinc oxide) 2665, Mn (manganese sulphate) 1190, I (calcium iodate) 197, Se (sodium selenite) 197, nicotinic acid 61.8, pantothenic acid 32.96, biotin 0.21, choline 125; IU: vit. A 29400, vit. $D_{3} 2200$, vit. E 1650 , vit. $K_{3} 1.03$, vit. $B_{1} 0.515$, vit. $B_{2} 14.7$, vit. $B_{12} 61.8$; DE - digestible energy, NDF - neutral detergent fibre, ADF - acid detergent fibre; nutrient contents except for lysine were analysed 
crossbred pigs (Landrace $\times$ Yorkshire) with body weight of $70 \mathrm{~kg}$ were selected and divided into four groups randomly, 5 pigs in each group. The pigs were fed with 4 different diets referring to the diets in groups $1-4$ in the later feeding period. The digestion trial was carried out for 7 days including 4-day preliminary preparation and 3-day trial. During the trial period, fresh excreta were collected daily from each pig. About $100 \mathrm{~g}$ samples were taken after mixing, and then $10 \%$ sulphuric acid was sprayed immediately and kept at $-20^{\circ} \mathrm{C}$. At last, the excreta samples from 3-day collection were mixed and dried at $65^{\circ} \mathrm{C}$, crushed and passed through a 40 mesh sieve for further use. Meanwhile, the diet samples were also taken for nutrient analysis. The total energy and acid insoluble ash (AIA) contents in the diets and faeces were measured. The energy digestibility of the diet was determined by $4 \mathrm{~N} \mathrm{HCl}$ insoluble ash. Energy digestibility $(\%)=100-(100 \times$ acid insoluble ash content in diet / acid insoluble ash content in faeces $\times$ total energy in faeces / total energy in diet). The dietary digestible energy was calculated based on energy digestibility.

The second digestion trial for nutrient digestibility determination was conducted at the end of later feeding period. Nutrient digestibility was measured with the same protocol as above.

\section{Determinations of faecal enzymatic activity}

Fresh excreta were collected at the later feeding period, and frozen at $-20{ }^{\circ} \mathrm{C}$ for further analysis. About $0.5 \mathrm{~g}$ faecal sample was put into a container with $4.5 \mathrm{ml}$ sterilized saline water, stirred for $10 \mathrm{~min}$, and the supernatant was used for enzymatic activity analysis. The filter paper activity (FPA) of cellulase was measured as the following: one unit of cellulase was defined as the amount of cellulase that released $1 \mu \mathrm{mol}$ of glucose per min at $\mathrm{pH} 4.8$ and $50{ }^{\circ} \mathrm{C}$ using filter paper as a substrate. Carboxymethyl-cellulose (CMC) activity of cellulase was measured with $1 \% \mathrm{CMC}$ as the substrate (Ghose, 1987). The amylase activity was determined by using soluble starch as the substrate (Leroy et al., 2008), one unit of amylase activity was defined as the amount of enzyme releasing $1 \mu \mathrm{mol}$ glucose per min. The protease activity was determined by the previous method (Sandhya et al., 2005), one unit of protease was defined as the amount of enzyme that liberated $1 \mu \mathrm{mol}$ tyrosine per min.

\section{Statistical analysis}

Experimental data were expressed as means and standard errors (mean $\pm \mathrm{SE}$ ), analysed as a single factor design by the analysis of variance (ANOVA) using IBM SPSS-Statistics Program 20.0 (IBM, New York, NY, USA, 2012). The means were evaluated with Tukey's multiple range test, and differences were considered statistically significance at $P<0.05$.

\section{Results}

\section{Nutrient compositions of natural maize straw and PMS}

In the Table 3 it is shown that NDF, ADF, cellulose and hemicellulose contents in PMS were significantly decreased $(P<0.05)$, while the total reducing sugar content was significantly increased $(P<0.05)$ in comparison with the natural maize straw.

Table 3. Nutrient compositions of natural maize straw and processed maize stover, $n=5$

\begin{tabular}{lcc}
\hline Indices, \% & Maize stover & Processed maize stover \\
\hline NDF & $79.3 \pm 1.31^{\mathrm{a}}$ & $38.7 \pm 0.42^{\mathrm{b}}$ \\
ADF & $59.2 \pm 2.00^{\mathrm{a}}$ & $38.3 \pm 0.76^{\mathrm{b}}$ \\
Cellulose & $41.3 \pm 2.31^{\mathrm{a}}$ & $17.5 \pm 0.72^{\mathrm{b}}$ \\
Hemicellulose & $20.0 \pm 1.18^{\mathrm{a}}$ & $0.0 \pm 0.00^{\mathrm{b}}$ \\
Reducing sugar & $4.8 \pm 0.12^{\mathrm{b}}$ & $18.1 \pm 1.06^{\mathrm{a}}$ \\
\hline
\end{tabular}

ab - means with different superscripts in the same row are significantly different at $P<0.05$; NDF - neutral detergent fibre, ADF - acid detergent fibre

\section{Digestible energy determination of PMS}

In the Table 4 we have shown that the dietary digestible energy in diets was significantly decreased with increasing PMS substitute rates for maize meal from 0 to $15 \%(P<0.05)$.

Table 4. Dietary digestible energy with different levels of processed maize stover (PMS) additions, $n=5$

\begin{tabular}{lcl}
\hline Groups $^{1}$ & PMS contents, $\%$ & $\begin{array}{l}\text { Dietary digestible } \\
\text { energy, MJ/kg }\end{array}$ \\
\hline 1 & 0 & $13.72 \pm 0.18^{\mathrm{a}}$ \\
2 & 5 & $13.30 \pm 0.20^{\mathrm{b}}$ \\
3 & 10 & $13.01 \pm 0.21^{\mathrm{b}}$ \\
4 & 15 & $12.59 \pm 0.14^{\mathrm{c}}$ \\
\hline
\end{tabular}

${ }^{1}$ groups according to Table 1 ; a,b,c - mean with different superscripts in the same column are significantly different at $P<0.05$

\section{Effect of PMS on production performance of pigs}

Swine production performance is presented in Table 5. In the first feeding period ADG was decreased significantly when $15 \%$ of PMS was added $(P<0.05)$ in comparison with other groups. There were no significant differences in ADG among the other groups $(P>0.05)$ except for the groups 
Table 5. Effect of dietary processed maize stover supplementation on swine production performance during both feeding stages, $n=3$

\begin{tabular}{|c|c|c|c|c|c|}
\hline \multirow{2}{*}{ Indices } & \multicolumn{5}{|l|}{ Groups $^{1}$} \\
\hline & 1 & 2 & 3 & 4 & 5 \\
\hline \multicolumn{6}{|l|}{$90-120$ days } \\
\hline initial weight, kg & $33.8 \pm 1.3$ & $33.5 \pm 1.0$ & $34.1 \pm 1.8$ & $33.2 \pm 2.0$ & $33.9 \pm 1.2$ \\
\hline final weight, kg & $49.9 \pm 0.5^{a}$ & $49.1 \pm 5.0^{\mathrm{a}}$ & $48.2 \pm 1.3^{\mathrm{ab}}$ & $45.3 \pm 2.0^{b}$ & $50.2 \pm 2.0^{a}$ \\
\hline$A D G, g / d$ & $538 \pm 16^{a}$ & $520 \pm 46^{\mathrm{a}}$ & $478 \pm 69^{\mathrm{ab}}$ & $420 \pm 35^{b}$ & $545 \pm 66^{a}$ \\
\hline ADFI, g/d & $1277 \pm 23$ & $1424 \pm 65$ & $1303 \pm 85$ & $1269 \pm 82$ & $1297 \pm 103$ \\
\hline FCR & $2.38 \pm 0.8^{b}$ & $2.75 \pm 0.14^{b}$ & $2.75 \pm 0.30^{b}$ & $3.04 \pm 0.22^{\mathrm{a}}$ & $2.39 \pm 0.09^{b}$ \\
\hline diarrhoea rate, \% & 8 & 4 & 5 & 4 & 5 \\
\hline \multicolumn{6}{|l|}{$120-150$ days } \\
\hline initial weight, kg & $51.3 \pm 1.4$ & $49.6 \pm 1.3$ & $49.9 \pm 1.1$ & $51.9 \pm 1.8$ & $51.3 \pm 1.4$ \\
\hline final weight, kg & $68.1 \pm 9.1$ & $69.0 \pm 1.3$ & $69.2 \pm 6.2$ & $7.5 \pm 8.2$ & $74.8 \pm 5.5$ \\
\hline$A D G, g / d$ & $635 \pm 53^{\mathrm{ab}}$ & $646 \pm 36^{\mathrm{ab}}$ & $616 \pm 87^{a b}$ & $582 \pm 58^{b}$ & $774 \pm 73^{a}$ \\
\hline ADFI, g/d & $1992 \pm 360$ & $2025 \pm 86$ & $1982 \pm 324$ & $2140 \pm 166$ & $2261 \pm 62$ \\
\hline FCR & $3.15 \pm 0.10^{\text {bc }}$ & $3.14 \pm 0.04^{b c}$ & $3.24 \pm 0.18^{b}$ & $3.68 \pm 0.08^{a}$ & $2.94 \pm 0.14^{c}$ \\
\hline diarrhoea rate, $\%$ & 4 & 0 & 2 & 0 & 1 \\
\hline
\end{tabular}

${ }_{1}^{1}$ groups according to Table $1 ;$ a,b,c - means with the different superscripts in the same row are significantly different at $P<0.05$; while means with the same or without superscripts in the same row are insignificantly different at $P>0.05$; ADG - average daily gain, ADFI - average daily feed intake, $F C R$ - feed conversion ratio $(F C R=A D F I / A D G)$, diarrhoea rate $(\%)=$ number of pigs with diarrhoea / total pigs $\times 100$

4 and 5. PMS had no significant effect on ADFI among 5 groups $(P>0.05)$. FCR in the group with $15 \%$ PMS addition was higher than that in other groups $(P<0.05)$. The diarrhoea rates in groups $2-5$ were decreased by $43-51 \%$ in comparison with the control group.

In the second feeding period, ADG in group 5 was higher than that in group $4(P<0.05)$. There were no significant differences of ADG among the other groups $(P>0.05)$. PMS did not significantly affect ADFI among 5 groups $(P>0.05)$. The lowest FCR was observed in group 5, then 2 and 1 ; the highest FCR was observed in pigs from group 4. The diarrhoea rates in groups $2-5$ were decreased by $38-96 \%$ in comparison with the control group. The adjusted DE levels in PMS diet during both feeding stages would help to improve swine production performance and FCR.

\section{Effect of different PMS addition levels in swine diets on nutrient digestibility}

Dry matter, energy, crude protein, NDF, ADF, calcium and phosphorus digestibilities significantly decreased as PMS addition increased from 5 to $15 \%$ $(P<0.05)$ (Table 6). Except for NDF digestibility, almost all the nutrient digestibilities in the control group were significantly higher than those in other groups $(P<0.05)$.

\section{Effect of dietary PMS supplementation on faecal enzyme activity in pigs}

Faecal CMC activity in groups supplemented with 10-15\% PMS was higher than in group supplemented with 5\% PMS and control group $(P<0.05)$ (Table 7). Filter paper activities (FPA) in the four PMS groups were significantly higher than that in the control group $(P<0.05)$.

Table 6. Effect of processed maize stover on nutrient digestibility in pigs, $n=5$

\begin{tabular}{|c|c|c|c|c|c|}
\hline \multirow{2}{*}{ Indices, \% } & \multicolumn{5}{|l|}{ Groups ${ }^{1}$} \\
\hline & 1 & 2 & 3 & 4 & 5 \\
\hline Dry matter & $87.1 \pm 1.0^{a}$ & $82.6 \pm 1.4^{b}$ & $78.8 \pm 1.3^{c}$ & $74.7 \pm 1.8^{d}$ & $76.4 \pm 0.2^{d}$ \\
\hline Energy & $87.5 \pm 1.1^{\mathrm{a}}$ & $81.2 \pm 2.5^{b}$ & $77.9 \pm 1.5^{b c}$ & $75.0 \pm 2.9^{c}$ & $76.8 \pm 0.3$ \\
\hline Crude protein & $82.6 \pm 1.6^{a}$ & $81.0 \pm 0.6^{\mathrm{ab}}$ & $74.7 \pm 0.4^{c}$ & $72.4 \pm 0.6^{d}$ & $79.2 \pm 1.9^{\mathrm{ab}}$ \\
\hline NDF & $84.0 \pm 1.7^{b}$ & $86.0 \pm 0.9^{a}$ & $82.8 \pm 1.0^{b c}$ & $80.3 \pm 1.0^{c}$ & $80.7 \pm 0.7^{c}$ \\
\hline ADF & $61.7 \pm 0.9^{a}$ & $62.3 \pm 1.0^{\mathrm{a}}$ & $48.4 \pm 1.4^{b}$ & $36.8 \pm 1.0^{d}$ & $41.7 \pm 1.0^{c}$ \\
\hline Calcium & $70.0 \pm 2.9^{a}$ & $53.9 \pm 3.1^{b}$ & $56.8 \pm 4.3^{b}$ & $53.0 \pm 1.6^{b}$ & $51.8 \pm 2.7^{b}$ \\
\hline Phosphorus & $57.6 \pm 0.0^{a}$ & $40.6 \pm 3.4^{b}$ & $44.3 \pm 0.6^{b}$ & $41.0 \pm 0.1^{b}$ & $43.5 \pm 0.8^{b}$ \\
\hline
\end{tabular}

${ }^{1}$ groups according to Table 1; a,b,d - means with different superscripts in the same row are significantly different at $P<0.05$; NDF - neutral detergent fibre, ADF - acid detergent fibre 
Table 7. Effect of dietary processed maize stover supplementation on faecal enzyme activity in pigs, $n=5, \mathrm{U} / \mathrm{g}$ faeces

\begin{tabular}{lllll}
\hline Groups $^{1}$ & CMC & FPA & Amylase & Protease \\
\hline 1 & $18.4 \pm 0.67^{\mathrm{b}}$ & $0.22 \pm 0.01^{\mathrm{c}}$ & $142.0 \pm 21.57^{\mathrm{b}}$ & $21.6 \pm 0.53^{\mathrm{bc}}$ \\
2 & $16.8 \pm 0.23^{\mathrm{b}}$ & $5.88 \pm 0.34^{\mathrm{b}}$ & $273.5 \pm 10.78^{\mathrm{a}}$ & $20.0 \pm 1.41^{\mathrm{c}}$ \\
3 & $21.1 \pm 1.12^{\mathrm{a}}$ & $8.03 \pm 1.12^{\mathrm{a}}$ & $174.4 \pm 5.39^{\mathrm{b}}$ & $16.8 \pm 0.13^{\mathrm{d}}$ \\
4 & $21.4 \pm 0.45^{\mathrm{a}}$ & $4.37 \pm 0.67^{\mathrm{b}}$ & $244.0 \pm 4.04^{\mathrm{a}}$ & $56.3 \pm 1.13^{\mathrm{a}}$ \\
5 & $22.8 \pm 1.34^{\mathrm{a}}$ & $5.85 \pm 0.06^{\mathrm{b}}$ & $139.1 \pm 33.69^{\mathrm{b}}$ & $23.7 \pm 0.61^{\mathrm{b}}$ \\
\hline
\end{tabular}

${ }^{1}$ groups according to Table 1 ; a,b,c - means with different superscripts in the same column are significantly different at $P<0.05$; FPA - filter paper activity of cellulase, $\mathrm{CMC}$ - carboxymethyl-cellulose activity of cellulase

The faecal amylase activity in groups supplemented with 5 and $15 \%$ PMS was significantly higher than that in other groups $(P<0.05)$. The faecal protease activity changing order was: group $4>$ group $5>$ group 1 and group $2>$ group $3(P<0.05)$.

\section{Discussion}

It was shown that physical pretreatment combined with microbial fermentation could decrease lignocellulose contents in maize straw and as a result could be a possible method to partly replace maize meal with such processed maize straw in swine diet. In the previous report it was indicated that the cellulose and hemicellulose contents in maize straw significantly decreased when the exploded maize straw was fermented for 7 days by Trichoderma koningii (Du et al., 2019) and this finding was also observed in this research. In general, lignocellulose structure is destroyed by steam explosion, which is conducive to microbial attack for making low-molecular carbohydrates.

Taking into account the results in both feeding trials, it could be concluded that the optimal levels of PMS in diets were below 10\% for the younger pigs and $15 \%$ for the older ones, indicating that PMS additions should agree with different ages of pigs. However, in line with increasing PMS addition there is observed a decreasing tendency in pig growth, especially visible in younger pigs. High lignocellulose and low DE contents in PMS and the immature digestive tract of young pigs can be the reason of such situation. Dietary fibre, as shown in other study, would inhibit pig growth when its content in growing pig diets was over $7.5 \%$ (Thacker and Haq, 2008); our present results correspond with this observation. The adjusted DE levels in PMS diets exerted no significant effects on swine production performance, indicating that DE level in PMS was enough to maintain pig growth (control group). Although pigs can adapt to relatively high-fibrelevel diet, dietary fibre is considered as an important factor affecting palatability and feed intake in pigs (Solà-Oriol et al., 2009). At the same time, high fibre content increases chyme wriggling speed to lower nutrient digestibility (Ndou et al., 2013). Due to intestinal filling, high fibre levels in the diet can reduce the amount of feed voluntarily consumed, thereby affecting pig energy intake (Da Silva et al., 2010). In another report it was shown that increasing level of dietary fibre can lead to an increase in feed intake, which may be related to the fact that fibre promotes the development of gastrointestinal tract in weaned piglets (Molist et al., 2014). Veum et al. (2009) in sow's experiment showed that gestation-lactation sow reproduction was increased when $13.35 \%$ ground wheat straw was added to the diets. However, it was observed that 2.5 or $5 \%$ of straw, sugar beet pulp, oat hulls or wheat middlings had no significant effect on piglet performance, but increased the incidence of post-weaning diarrhoea and deceased feed efficiency and nutrient digestibility (Berrocoso et al., 2015). The reasons of the different pig responses to straw additions may be due to the different straw treated methods, pig types, feeding conditions, straw sources and addition levels.

Nutrient digestibility is necessary to accurately formulate animal diet; therefore, DE evaluation of PMS is very important before swine feeding experiment. In the previous report it was indicated that digestive energy of maize germ meal was $13.93 \mathrm{MJ} / \mathrm{kg}$ in pigs (Shi et al., 2018), corresponding with DE level in the control group in this study. With the addition of $15-55 \%$ beet dregs containing $22 \%$ soluble dietary fibre and $47.1 \%$ insoluble dietary fibre to the basal diet. DE levels were decreased from 14.7 to $13.1 \mathrm{MJ} / \mathrm{kg}$ (Zhang et al., 2013). There was a negative correlation between NDF level and digestible energy in growing pig diets, in which digestible energy was decreased by $0.81 \%$ when dietary NDF level was increased by $1 \%$ (Noblet et al., 1994). The reason why PMS addition decreases nutrient digestibility may be due to the crude fibre in diets which accelerates the nutrients passing through the digestive tract. 
As it was previously reported, high dietary fibre level would prevent the contact of enzyme with feed to reduce the digestion of nutrients (Ehle et al., 1982; Le Gall et al., 2009). Also, dietary fibre was able to affect digestion and absorption of minerals such as $\mathrm{Ca}, \mathrm{P}, \mathrm{Cu}, \mathrm{Fe}$ (Noblet and Le Goff, 2001; De Leeuw et al., 2008). Wilfart et al. (2007) by adding $20-40 \%$ wheat bran to the wheat-barley-soybean meal diet, found that increasing dietary fibre level significantly reduced the apparent digestibility of dry matter, organic matter, crude protein and energy. In general, PMS addition in this study caused negative effect on nutrient digestibility, especially when added in high amounts.

Low diarrhoea rates in pigs fed diets supplemented with PMS may be due to cellulose nutrient function as well as the enzymes produced during microbial fermentation. It was reported that increasing dietary fibre content could reduce duration and severity of diarrhoea after piglets weaning ( $\mathrm{Yu}$ et al., 2016; Mpendulo et al., 2018). Longland (1993) also reported that piglets had almost no obvious diarrhoea by adding wood cellulose (Solka-floc; S; Brown \& Co., Berlin, NH, USA) to the pre-weaning piglet diet, and this fact was confirmed in our study. However, Berrocoso et al. (2015) reported that fibre addition increased piglet diarrhoea and suggested that it may be due to the immature digestive tract of piglets or the different fibre sources.

Porcine endogenous digestive enzymes are maximized in the pig jejunum (Lackeyram et al., 2010). Molist et al. (2014) reported that adding fibre in animal diet increased the counts of fibrolytic bacteria and short-chain fatty acid synthesis in the intestine. High activities of CMC and FPA enzyme in this study may be related to the enzymes in PMS produced during microbial fermentation or the high counts of cellulose-degrading bacteria in swine gut. However, high CMC and FPA enzyme activities caused by PMS additions had no effect on improving ADF and NDF digestibilities. This may be due to the not sufficient enzyme activity to hydrolyse the increased amount of fibre.

\section{Conclusions}

In order to increase the application potential of maize stover in pig diets, combination of steam explosion and Aspergillus oryzae fermentation was used to reduce the contents of cellulose and hemicelluloses. It was shown that adding around 10\% processed maize stover (PMS) to pig diets in order to replace the same amount of maize meal was practicable for pig production performance. The valuable information on solving partly grain shortage in pig diets with PMS was presented.

\section{Acknowledgements}

The study was supported by the National Natural Science Foundation of China (31702148), Henan Key Scientific and Technological Projects (182102110062), and Xinxiang Key Scientific and Technological Project (ZD19005).

\section{References}

Aguilar D.L., Rodriguez-Jasso M., Zanuso E., de Rodriguez D.J., Amaya-Delgado L., Sanchez A., Ruiz HA., 2018. Scale-up and evaluation of hydrothermal pretreatment in isothermal and non-isothermal regimen for bioethanol production using agave bagasse. Bioresour. Technol. 263, 112-119, https://doi. org/10.1016/j.biortech.2018.04.100

AOAC, 1990. Official Methods of Analysis of the Association of Official Analytical Chemists. $15^{\text {th }}$ Edition. Arlington, VA (USA)

Berrocoso J.D., Menoyo D., Guzmán P., Saldaña B., Cámara L., Mateos G.G., 2015. Effects of fiber inclusion on growth performance and nutrient digestibility of piglets reared under optimal or poor hygienic conditions. J. Anim. Sci. 93, 3919-3931, https:// doi.org/10.2527/jas.2015-9137

Chang J., Zhang Q.G., Yang H.J., Yin Q.Q., Wang P., Wang Q.W., 2015. Effect of biological corn stover replacing partial corn meal on production performance, nutrient metabolic rates and carcass characteristics of broilers. Indian J. Anim. Res. 49, 474-481, https://doi.org/10.5958/0976-0555.2015.00122.3

Chen H., Wang W., Degroote J., Possemiers S., Chen D., De Smet S., Michiels J., 2015. Arabinoxylan in wheat is more responsible than cellulose for promoting intestinal barrier function in weaned male piglets. J. Nutr. $145,51-58$, https://doi. org/10.3945/jn.114.201772

Da Silva C.S., Van Den Borne J.J., Gerrits W.G., Kemp B., Bolhuis J.E., 2010. Effects of dietary fibers with different physicochemical properties on feeding motivation in adult female pigs. Physiol. Behav. 107, 218-230, https://doi.org/10.1016/j. physbeh.2012.07.001

De Leeuw J.A., Bolhuis J.E., Bosch G., Gerrits W.J.J., 2008. Effects of dietary fibre on behaviour and satiety in pigs. Proc. Nutr. Soc. 67, 334-342, https://doi.org/10.1017/S002966510800863X

Du C., Nan X., Wang K., Zhao Y., Xiong B., 2019. Evaluation of the digestibility of steam-exploded wheat straw by ruminal fermentation, sugar yield and microbial structure in vitro. RSC Adv. 9, 41775-41782, https://doi.org/10.1039/C9RA08167D

Ehle F.R., Jeraci J.L., Robertson J.B., Vansoest P.J., 1982. The influence of dietary fiber on digestibility, rate of passage and gastrointestinal fermentation in pigs. Anim. Sci. 55, 1071-1706, https://doi.org/10.2527/jas1982.5551071x

Ghose T.K., 1987. Measurement of cellulase activities. Pure Appl. Chem. 59, 257-268, https://doi.org/10.1351/pac198759020257

Graminha E.B.N., Goncalves A.Z.L., Pirota R.D.P.B., Balsalobre M.A.A., Silva Da R., Gomes E., 2008. Enzyme production by solidstate fermentation: application to animal nutrition. Anim. Feed Sci. Technol. 144, 1-22, https://doi.org/10.1016/j. anifeedsci.2007.09.029 
He B.B., Bai Y., Jiang L.L., Wang W., Li T.T., Liu P., Tao S.Y., Zhao J.C., Han D.D., Wang J.J., 2018. Effects of oat bran on nutrient digestibility, intestinal microbiota, and inflammatory responses in the hindgut of growing pigs. Int. J. Mol. Sci. 19, 2407, https://doi.org/10.3390/ijms19082407

Jurgens M.H., 1997. Animal Feeding and Nutrition. $8^{\text {th }}$ Edition. Kendall/ Hunt Publishing Company. Dubuque, IA (USA)

Kaur A., Kuhad R.C., 2019. Valorization of rice straw for ethanol production and lignin recovery using combined acid-alkali pre-treatment. Bioenergy Res. 12, 570-582, https://doi. org/10.1007/s12155-019-09988-3

Lackeyram D., Yang C., Archbold T., Swanson K.C., Fan M.Z., 2010. Early weaning reduces small intestinal alkaline phosphatase expression in pigs. J. Nutr. 140, 461-468, https://doi. org/10.3945/jn.109.117267

Le Gall M., Warpechowski M., Jaguelin-Peyraud Y., Noblet J., 2009. Influence of dietary fibre level and pelleting on the digestibility of energy and nutrients in growing pigs and adult sows. Animal 3, 352-359, https://doi.org/10.1017/ S1751731108003728

Leroy C., Delbarre C., Ghillebaert F., Compere C., Combes D., 2008. Effects of commercial enzymes on the adhesion of a marine biofilm-forming bacterium. Biofouling 24, 11-22, https://doi. org/10.1080/08927010701784912

Longland A.C., Low A.G., Quelch D.B., Bray S.P., 1993. Adaptation to the digestion of non-starch polysaccharide in growing pigs fed on cereal or semi-purified basal diets. Br. J. Nutr. 70, 557-566, https://doi.org/10.1079/BJN19930148

Luo Y., Chen H., Yu B., He J., Zheng P., Mao X., Yu J., Luo J., Huang Z., Chen D., 2018. Dietary pea fibre alters the microbial community and fermentation with increase in fibre degradation- associated bacterial groups in the colon of pigs. J. Anim. Physiol. Anim. Nutr. 102, e254-e261, https://doi. org/10.1111/jpn.12736

Miller G.L., 1959. Use of dinitrosalicylic acid reagent for determination of reducing sugar. Anal. Chem. 31, 426-428, https://doi. org/10.1021/ac60147a030

Molist F., Van Oostrum M., Pérez J.F., Mateos G.G., Nyachoti C.M., Van Der Aar P.J., 2014. Relevance of functional properties of dietary fibre in diets for weanling pigs. Anim. Feed. Sci. Technol. 189, 1-10, https://doi.org/10.1016/j.anifeedsci.2013.12.013

Mourtzinis S., Cantrell K.B., Arriaga F.J., Balkcom K.S., Novak J.M., Frederick J.R., Karlen D.L., 2016. Carbohydrate and nutrient composition of corn stover from three southeastern USA locations. Biomass Bioenerg. 85, 153-158, https://doi. org/10.1016/j.biombioe.2015.11.031

Mpendulo C.T., Chimonyo M., Ndou S.P., Bakare A.G., 2018. Fiber source and inclusion level affects characteristics of excreta from growing pig. Asian-Australas. J. Anim. Sci. 31 755-762, https://doi.org/10.5713/ajas.14.0611

Ndou S.P., Gous R.M., Chimonyo M., 2013. Prediction of scaled feed ntake in weaner pigs using physicochemical properties of fibrous feeds. Br. J. Nutr. 110, 774-780, https://doi. org/10.1017/S0007114512005624

Noblet J., Fortune H., Shi X.S., Dubois S., 1994. Effect of body weight on NE value of feeds for growing pigs. J. Anim. Sci. 72, 648-657, https://doi.org/10.2527/1994.723648x

Noblet J., Le Goff G.I., 2001. Effect of dietary fibre on the energy value of feeds for pigs. Anim. Feed. Sci. Technol. 90, 35-52, https:// doi.org/10.1016/S0377-8401(01)00195-X
Saha B.C., Iten L.B., Cotta M.A., Wu Y.V., 2005. Dilute acid pretreatment, enzymatic saccharification and fermentation of wheat straw to ethanol. Process Biochem. 40, 3693-3700, https://doi.org/10.1016/j.procbio.2005.04.006

Sandhya C., Sumantha A., Szakac G., Pandey A., 2005. Comparative evaluation of neutral protease production by Aspergillus oryzae in submerged and solid-state fermentation. Process Biochem. 40, 2689-2694, https://doi.org/10.1016/j.procbio.2004.12.001

Shi M., Liu Z., Wang H., Shi C., Zhang S., 2018. Determination and prediction of the digestible and metabolizable energy contents of corn germ meal in growing pigs. Asian-Australas. J. Anim. Sci. 32, 405-412, https://doi.org/10.5713/ajas.17.0891

Siddhu M.A.H., Li W., He Y., Liu G., Chen C., 2019. Steam explosion pretreatment of rice straw to improve structural carbohydrates anaerobic digestibility for biomethanation. Environ. Sci. Pollut. Res. 26, 22189-22196, https://doi.org/10.1007/s11356-01905382-w

Slavin J.L., Savarino V., Paredes-Diaz A., Fotopoulos G., 2009. A review of the role of soluble fiber in health with specific reference to wheat dextrin. J. Int. Med. Res. 37, 1-17, https:// doi.org/10.1177/147323000903700101

Solà-Oriol D., Roura E., Torrallardona D., 2009. Feed preference in pigs: Effect of cereal sources at different inclusion rates. J. Anim. Sci. 87, 562-570, https://doi.org/10.2527/jas.20080949

Thacker P.A., Haq I., 2008. Nutrient digestibility, performance and carcass traits of growing-finishing pigs fed diets containing graded levels of dehydrated lucerne meal. J. Sci. Food Agric. 88, 2019-2025, https://doi.org/10.1002/jsfa.3314

Van Soest P.J., Robertson J.B., Lewis B.A., 1991. Methods for dietary fiber, neutral detergent fiber, and nonstarch polysaccharides in relation to animal nutrition. J. Dairy Sci. 74, 3583-3597, https://doi.org/10.3168/jds.S0022-0302(91)78551-2

Veum T.L., Crenshaw J.D., Crenshaw T.D., Cromwell G.L., Easter R.A., Ewan R.C., Nelssen J.L., Miller E.R., Pettigrew J.E., Ellersieck M.R., 2009. The addition of ground wheat straw as a fiber source in the gestation diet of sows and the effect on sow and litter performance for three successive parities. J. Anim. Sci. 87, 1003-1012, https://doi.org/10.2527/ jas.2008-1119

Wang P., Liu C., Chang J., Yin Q.Q., Huang W., Liu Y., Dang X.W., Gao T.Z., Lu F.S., 2019. Effect of physicochemical pretreatments plus enzymatic hydrolysis on the composition and morphologic structure of corn straw. Renew. Energ. 138, 502-508, https://doi.org/10.1016/..renene.2019.01.118

Wilfart A., Montagne L., Simmins H., Noblet J., Van Milgen J., 2007. Effect of fibre content in the diet on the mean retention time in different segments of the digestive tract in growing pigs. Livest. Sci. 109, 27-29, https://doi.org/10.1016/j.livsci.2007.01.032

Yu C., Zhang S., Yang Q., Peng Q., Zhu J., Zeng X., 2016. Effect of high fibre diets formulated with different fibrous ingredients on performance, nutrient digestibility and faecal microbiota of weaned piglets. Arch. Anim. Nutr. 70, 263-277, https://doi.org /10.1080/1745039X.2016.1183364

Zhang W., Li D., Liu L., Zang J., Duan Q., Yang W., Zhang L., 2013. The effects of dietary fiber level on nutrient digestibility in growing pigs. J. Anim. Sci. Biotechnol. 4, 17, https://doi. org/10.1186/2049-1891-4-17 